\title{
Pleiotropic Mutants of Chinese Hamster Cells with Altered Cytidine 5'-Triphosphate Synthetase
}

\author{
Ernest H. Y. Chu, ${ }^{1,2}$ John D. McLaren, ${ }^{1}$ I-Chian Li, ${ }^{1}$ and Barbara Lamb \\ Received 26 Oct. 1983-Final 20 Apr. 1984
}

Following chemical mutagenesis and multiple-step indirect selection, four clones of Chinese hamster V79 cells were isolated which exhibited auxotrophy for thymidine, deoxycytidine, or deoxyuridine but not for cytidine or uridine. All were resistant to uridine, 3-deazauridine, 5-fluorouridine, thymidine, and cytosine arabinoside at concentrations that were toxic to wild-type V79 cells. The cytidine 5'-triphosphate (CTP) and deoxycytidine 5 -triphosphate (dCTP) pools in the mutants were expanded, but the uridine 5 'triphosphate (UTP) pool either decreased or remained unchanged relative to the wild-type level. Furthermore, since the parental cells appear to be deficient in $\mathrm{C} C M P$ deaminase activity and CTP (or one of its metabolites) has been shown to inhibit uridine 5'-diphosphate (UDP) reduction, an elevated CTP level should lead to the observed thymidine auxotrophy. It also explains the joint resistance of mutant clones to thymidine and cytosine arabinoside. The change in the ratio of intracellular dCTP to thymidine 5 -triphosphate (dTTP) may be responsible for the elevation in the rates of spontaneous mutations in these mutants.

KEY WORDS: cytidine $5^{\prime}$-triphosphate synthetase; Chinese hamster cells; pyrimidine metabolism; $K_{m}$ mutants; nucleotide pools; feedback inhibition.

\section{INTRODUCTION}

Cytidine 5'-triphosphate synthetase (CTPS; EC 6.3.4.2) is a rate-limiting enzyme which catalyzes the irreversible conversion of uridine 5 '-triphosphate

This work was supported by Grant GM 30608 from the U.S. Public Health Service.

${ }^{1}$ Lawrence D. Buhl Center for Human Genetics, Department of Human Genetics, University of Michigan Medical School, Ann Arbor, Michigan 48109.

${ }^{2}$ To whom correspondence should be addressed. 
(UTP) to CTP. The enzyme activity has been detected in a variety of mammalian cells (Genchev, 1973; Brockman et al., 1975). CTPS activity is significantly increased in tumor cells of rat liver and kidney, compared to normal cells (Williams et al., 1978). Robert de Saint Vincent and co-workers $(1979,1980)$ reported that a class of variant Chinese hamster fibroblasts, isolated on the basis of their resistance to cytosine arabinoside or excess thymidine, exhibited expanded pools of both CTP and dCTP, while their UTP pools were not increased. It was further shown (Robert de Saint Vincent and Buttin, 1980) that these variants expressed CTPS activity at the wild-type levels, but the enzyme partially resisted inhibition imposed by CTP on the wild-type enzyme. Mutations affecting a key enzyme such as CTPS could lead to profound effects on the overall mutability of the cells through the abnormal supply of intracellular deoxyribonucleotide pools. If such mutants at either the structural or the regulatory gene locus can be found, it may allow us an estimate of the physiological importance of this enzyme in the network of the highly regulated pyrimidine metabolism of mammalian cells. To this end, we have taken a mutational approach by introducing stable genetic defects that may influence the activity of CTPS in a cultured mammalian cell system. In this paper, we describe the isolation and initial characterization of four CTPS mutants of Chinese hamster cells which exhibit modified kinetic and regulatory properties of the enzyme, in addition to an increased mutability and multiple changes of phenotypes. The early phase of this work has been summarized (Chu et al., 1982).

\section{MATERIALS AND METHODS}

Cell Culture and Cell Fusion. A Chinese hamster cell line (V79) derived originally from the lung tissue of a male animal was used (Ford and Yerganian, 1958). The growth medium was modified Eagle's minimum essential medium containing Earle's balanced salt solution, a 50\% increase of vitamins and essential amino acids except L-glutamine, a $100 \%$ increase of nonessential amino acids, $1 \mathrm{~mm}$ sodium pyruvate, and $5 \%(\mathrm{v} / \mathrm{v})$ fetal calf serum (FCS). For testing the nutritional requirements, dialyzed FCS was used. All cultures were grown at $37^{\circ} \mathrm{C}$ in a humidified atmosphere of $5 \% \mathrm{CO}_{2}$ in air.

AUX $\mathrm{Bl}$ is a mutant clone of Chinese hamster ovary (CHO) cells with multiple requirements for glycine, adenine, and thymidine (dThd) (McBurney and Whitmore, 1974) and deficient in folylpolyglutamate synthetase (Taylor and Hanna, 1977). The cell line was maintained in medium supplemented with $10^{-5} \mathrm{M}$ dThd.

The technique of polyethylene glycol-induced cell fusion was essentially that of Davidson et al. (1976). 
Chemicals. 3-Deazauridine (DAU), 5-fluorouridine, 1- $\beta$-D-arabinofuranosylcytosine (araCyt), nucleosides, and nucleotides were obtained from Sigma Chemical Co. Radiochemicals were obtained from New England Nuclear Co. or Amersham Radiochemical Co.; poly(dA-dT) and poly(dI$\mathrm{dC}$ ) were from P. L. Biochemicals, Inc.; RNA and DNA polymerases were from Boehringer-Mannheim Biochemical Co. Ethyl methanesulfonate (EMS) was purchased from Eastman Kodak Chemical Co.

Tri- $n$-octylamine (TOA) and 1,1,2-trichlorotrifluoroethane (Freon) were obtained from Aldrich Chemical Co. High-performance liquid chromatography (HPLC) columns were purchased from Whatman Chemical Separation, Inc. HPLC-grade ammonium phosphate was purchased from Fisher Scientific Co., HPLC-grade methyl alcohol from either Burdick and Jackson or Mallinckrodt, and a GSWP-type filter $(0.22 \mu \mathrm{m})$ from Millipore Corp.

3-Deazauridine Cytotoxicity. Cells at $7.4 \times 10^{4} / 6-\mathrm{cm}$ plate were inoculated in triplicate in a medium containing $2 \mathrm{mM}$ L-glutamine and $2 \mu \mathrm{M}$ Cyd and incubated for $16 \mathrm{hr}$. Cytidine at this concentration did not affect the uptake of Urd. The medium in the control cultures was changed to that supplemented with $2 \mathrm{mM}$ glutamine; in the treated series the fresh medium contained $4 \times 10^{-5}$ or $4 \times 10^{-4} \mathrm{M}$ DAU. At various times the cells from appropriate samples were washed, collected, and lysed with $1 \mathrm{~N} \mathrm{NaOH}$. An aliquot of the lysate was measured for absorbance at $260 \mathrm{~nm}$.

In order to test the possible reversal of the DAU toxicity by Cyd, $7.2 \times$ $10^{4}$ cells $/ 6-\mathrm{cm}$ plate were inoculated in medium containing $2 \mathrm{~mm}$ glutamine but without Cyd. After $5 \mathrm{hr}$ of incubation, the medium was replaced either with the same medium or with that containing various concentrations of Cyd and DAU. All cultures were terminated after $64 \mathrm{hr}$, and the total cell growth per culture was measured and expressed as changes in optical density at 260 $\mathrm{nm}$. The reversal of DAU cytotoxicity was also measured in terms of the colony-forming ability of the parental V79 and mutant cells in the concurrent presence of DAU and one of several pyrimidine nucleosides.

Isolation of Variants. The selection scheme was patterned after that of Urlaub and Chasin (1980), who designed an indirect selective method for autosomal recessive mutations in near-diploid $\mathrm{CHO}-\mathrm{Kl}$ cells that are deficient in dihydrofolate reductase activity. They showed the effectiveness of $\left[{ }^{3} \mathrm{H}\right] \mathrm{dUrd}$ as a killing agent of $\mathrm{CHO} \mathrm{Kl}$ cells and the avoidance of the killing with methotrexate, which binds tightly to dihydrofolate reductase. A heterozygote was first obtained and homozygous recessive mutants were isolated following mutagenic treatment of the heterozygote. On the assumption that the locus for CTPS is autosomal in the Chinese hamster, and that 3-deaza UTP is an effective competitive inhibitor of the hamster enzyme (McPartland 
et al., 1974; Brockman et al., 1975), we applied the same strategy for the indirect selection for possible CTPS mutants in V79 cells.

Measurement of Nucleotides by HPLC. Pellets of whole cells were stored at $-70^{\circ} \mathrm{C}$ prior to nucleotide extraction by a modified procedure of Pogolotti and Santi (1982). The frozen cell pellet was extracted with 200 to $400 \mu \mathrm{l}$ solution of $0.6 \mathrm{M}$ trichloroacetic acid (TCA) containing $\mathrm{L}-\left[{ }^{14} \mathrm{C}(U)\right]$ leucine by vortexing in a polypropylene microfuge tube. After $10 \mathrm{~min}$ on ice, the mixture was centrifuged at $10,000 \mathrm{~g}$ for $1 \mathrm{~min}$ and the supernatant transferred to a new tube. TCA was removed from the sample by adding $220-500 \mu \mathrm{l}$ cold Freon containing $0.5 \mathrm{M} \mathrm{TCA}$, vortexing, and centrifuging for $1 \mathrm{~min}$. The lower phase, containing Freon and TCA, was removed with a hypodermic syringe, leaving the upper aqueous phase, which contains the nucleotides. The extract was stored at $-70^{\circ} \mathrm{C}$ until use.

High-performance liquid chromatography (HPLC) was performed using a Beckman 332 gradient liquid chromatograph and an Hitachi variablewavelength detector. Samples of each extract were injected onto a Partisil 10 SAX/25 cm analytical anion-exchange column; a pellicular SAX anionexchange guard column was used between the injector and the analytical column, and a Solvecon column filled with silica gel was used between the pumps and the injector. The method for measuring nucleotides was modified from that of Rose and Brockman (1977). Buffer A $\left(5 \mathrm{mM} \mathrm{NH}_{4} \mathrm{H}_{2} \mathrm{PO}_{4}, p \mathrm{H}\right.$ $2.8)$ and buffer $\mathrm{B}\left(0.75 \mathrm{M} \mathrm{NH}_{4} \mathrm{H}_{2} \mathrm{PO}_{4}, p \mathrm{H} \mathrm{3.9)}\right.$ were used to develop, at a flow rate of $2 \mathrm{ml} / \mathrm{min}$ for $40 \mathrm{~min}$, a linear gradient from $100 \%$ buffer $\mathrm{A}$ to $100 \%$ buffer B. The peaks were monitored at $260 \mathrm{~nm}$ and integrated using a Hewlett--Packard 3390A integrator. The identification of peaks from the cell extracts was based on the retention times of the standards.

Enzymatic Determination of Nucleoside Triphosphates. Exponentially growing cells (20 to $40 \times 10^{6} /$ cell line) were collected and nucleotides extracted by the perchloric acid method (Cheng et al., 1975). The acidinsoluble fraction was used for DNA determination (Giles and Myers, 1965). The acid-soluble fraction was used for nucleotide pool measurements after appropriate dilutions. The extracts were stored at $-20^{\circ} \mathrm{C}$ if not used immediately.

The intracellular dCTP and dTTP pools were measured according to the method of Skoog (Lindberg and Skoog, 1970; Skoog, 1970). The assay relies on a poly $(\mathrm{dA}-\mathrm{dT})$ - or poly (dI-dC)-primed DNA synthesis, with either dTTP or dCTP acting as the limiting nucleotide. The incorporation of $\left[{ }^{3} \mathrm{H}\right] \mathrm{dATP}$ or $\left[{ }^{3} \mathrm{H}\right] \mathrm{dGTP}$, as catalyzed by Kornberg DNA polymerase, into acid-insoluble product was exclusively dependent on the amount of the limiting nucleotide. For dCTP assay, a 100- $\mu$ l reaction mixture contained $100 \mathrm{mM} \mathrm{Tris}-\mathrm{HCl}, p \mathrm{H}$ 8.0, $5 \mathrm{mM} \mathrm{MgCl}_{2}, 1 \mathrm{mM}$ 2-mercaptoethanol, $40 \mu \mathrm{M}$ poly(dI-dC), $1 \mu \mathrm{M}$ 
$\left[{ }^{3} \mathrm{H}\right] \mathrm{dGTP}$ (final $1 \mathrm{Ci} / \mathrm{mmol}, 20 \mu \mathrm{Ci} / \mathrm{ml}$ ), 4.5-5 U/ml Kornberg DNA polymerase, and cell extract. For dTTP assay, a $100-\mu$ l reaction mixture contained $100 \mu \mathrm{M} \quad \mathrm{KH}_{2} \mathrm{PO}_{4}$ buffer, $p \mathrm{H} \mathrm{7.4,10 \textrm {mM } \mathrm { MgCl }}, 1 \mathrm{mM} \mathrm{2-}$ mercaptoethanol, $20 \mu \mathrm{M}$ poly $\left(\mathrm{dA}-\mathrm{dT}\right.$ ), $2 \mu \mathrm{M}\left[{ }^{3} \mathrm{H}\right] \mathrm{dATP}$ (final $1 \mathrm{Ci} / \mathrm{mmol}, 10$ $\mu \mathrm{Ci} / \mathrm{ml}), 1 \mathrm{U} / \mathrm{ml}$ Kornberg DNA polymerase, and cell extract.

All pool determinations were reproducible with a variation of less than $20 \%$ in independent experiments. The data presented are the average of at least two determinations.

\section{RESULTS}

3-Deazauridine Cytotoxicity. Figure 1 shows the inhibition of growth of V79 cells by DAU. At the two concentrations tested, there was a marked suppression of cell growth during the first $100 \mathrm{hr}$ in the presence of this Urd analogue, followed by a decline in population size due likely to cell death. This inhibition could, however, be reversed in a dose-dependent manner if Cyd was also present in the medium (Fig. 2). The reversal of DAU cytotoxicity was also evident in terms of the colony-forming ability of cells when one of several pyrimidine nucleosides was added (Table I). The effect of DAU can be reversed by Cyd and dCyd and, to a lesser extent, by Urd but not by dThd or dUrd. The data also show that the variants we isolated (see below) were more resistant to DAU than V79 cells.

Isolation of CTPS Variants. The killing of V79 cells by $\left[5-{ }^{3} \mathrm{H}\right] \mathrm{Urd}$ could be prevented by $4 \times 10^{-4} \mathrm{M}$ DAU and $10^{-5} \mathrm{M}$ Cyd (Fig. 3). A

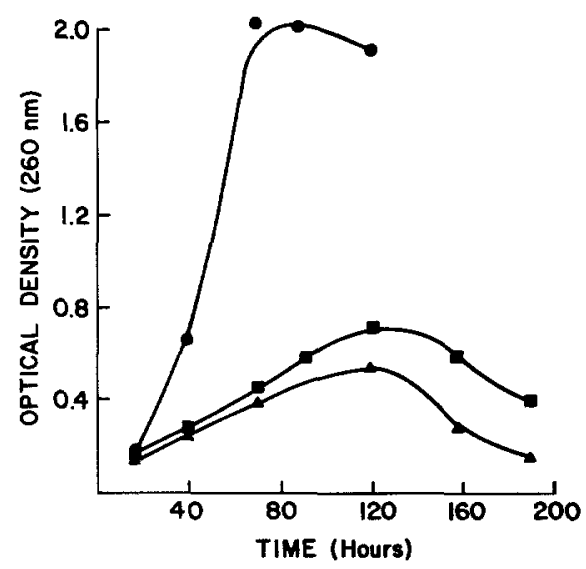

Fig. 1. 3-Deazauridine (DAU) cytotoxicity in Chinese hamster V79 cells. Control (๑); $4 \times$ $10^{-5} \mathrm{M} \operatorname{DAU}(\mathbf{\mathbb { \sigma }}) ; 4 \times 10^{-4} \mathrm{M} \operatorname{DAU}(\mathbf{A})$. 


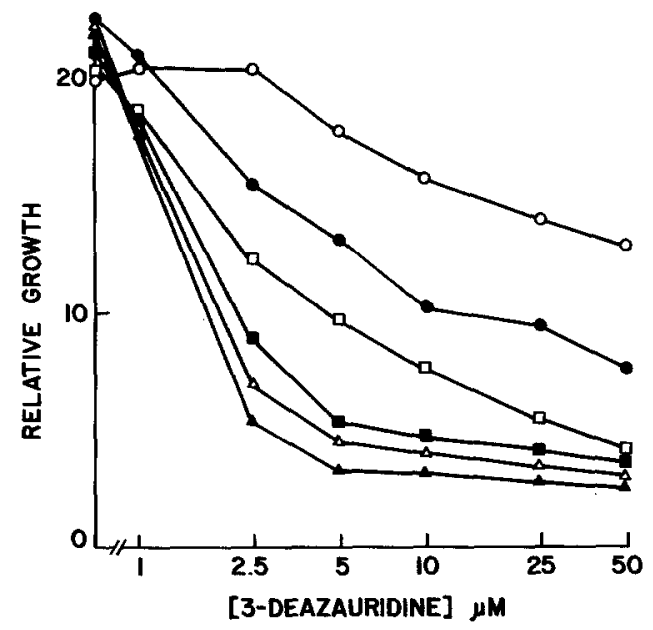

Fig. 2. Reversal of 3-deazauridine cytotoxicity in V79 cells by the concurrent presence of various concentrations of exogenous cytidine in the medium: $1 \times 10^{-5} \mathrm{M}$ $(0) ; 5 \times 10^{-6} \mathrm{M}(\bullet) ; 2.5 \times 10^{-6} \mathrm{M}(\square) ; 1 \times 10^{-6} \mathrm{M}$

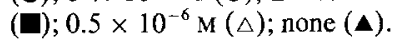

population of V79 cells was mutagenized with EMS ( $400 \mu \mathrm{g} / \mathrm{ml}, 16 \mathrm{hr})$. After 1 week for recovery and phenotypic expression in medium enriched with Cyd and dThd, the cells were treated for $24 \mathrm{hr}$ with $\left[5-{ }^{3} \mathrm{H}\right] \mathrm{Urd}, 10^{-5} \mathrm{M} \mathrm{DAU}$, and $10^{-5} \mathrm{M}$ Cyd. The surviving cells were allowed to proliferate, followed by two cycles of the same treatment with $\left[5-{ }^{3} \mathrm{H}\right] \mathrm{Urd}$. One of the ten clones isolated, CPH 2-2, was more sensitive to inhibition of growth by DAU and a reduced CTPS activity, compared to the parental cells. The CPH 2-2 cells were again treated with EMS. After a 6-day expression, $3 \times 10^{6}$ cells were treated for 24 hr with $\left[5{ }^{3} \mathrm{H}\right] \mathrm{Urd}$ and the surviving cells replated at $10^{5}$ cells $/ 6-\mathrm{cm}$ plate.

Table I. Effect of Pyrimidine Nucleosides on the Inhibition of Growth of V79 and CTPS 42 Cells with 3-Deazauridine (DAU)

\begin{tabular}{|c|c|c|c|c|c|c|c|c|}
\hline \multirow[b]{4}{*}{ Cell } & \multicolumn{8}{|c|}{ Relative plating efficiency ( $\%$ ) } \\
\hline & \multirow{3}{*}{$\begin{array}{l}\text { Normal } \\
\text { medium }\end{array}$} & \multirow{2}{*}{\multicolumn{2}{|c|}{ DAU }} & \multicolumn{5}{|c|}{$\operatorname{DAU}(10 \mu \mathrm{M})+$} \\
\hline & & & & \multirow{2}{*}{$\begin{array}{c}\text { Cyd } \\
(10 \mu \mathrm{M})\end{array}$} & \multirow{2}{*}{$\begin{array}{c}\mathrm{dCyd} \\
(40 \mu \mathrm{M})\end{array}$} & \multirow{2}{*}{$\begin{array}{l}\text { Urd } \\
(10 \mu \mathrm{M})\end{array}$} & \multirow{2}{*}{$\begin{array}{c}\mathrm{dUrd} \\
(40 \mu \mathrm{M})\end{array}$} & \multirow{2}{*}{$\begin{array}{c}\text { dThd } \\
(10 \mu \mathrm{M})\end{array}$} \\
\hline & & $5 \mu \mathrm{M}$ & $10 \mu \mathrm{M}$ & & & & & \\
\hline V79 & 100 & 1.2 & 0 & 109 & 97 & 66 & 0 & 0 \\
\hline 42 & 100 & 15.7 & 6.7 & 79 & 92 & 87 & 4 & 2 \\
\hline
\end{tabular}




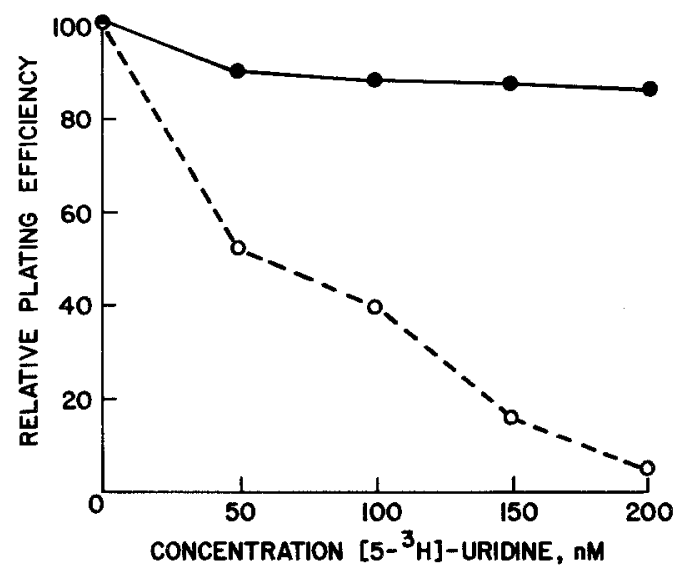

Fig. 3. Killing of Chinese hamster V79 cells by [5$\left.{ }^{3} \mathrm{H}\right]$ uridine ( $25 \mathrm{Ci} / \mathrm{mmol}, 24-\mathrm{hr}$ exposure) $(\mathrm{O})$ and its reversal by $4 \times 10^{-4} \mathrm{M}$ 3-deazauridine and $10^{-5} \mathrm{M}$ cytidine (๑).

Fifty colonies from a total of 12 plates were isolated and tested in media containing dialyzed FCS, DAU, Cyd, and/or dThd. Four (CTPS 42, 43, 44, and 46) of the eight clones could not grow in medium supplemented with dialyzed fetal calf serum with or without $10^{-5} \mathrm{M}$ Cyd but exhibited a dependence on dThd. These isolates were studied further.

Nutritional and Cytotoxic Response to Exogenous Nucleosides and Analogues. V79 cells were exposed to graded concentrations of Cyd in the presence or absence of $16 \mu \mathrm{M}$ dThd (Robert de Saint Vincent and Buttin, 1980). The cells were sensitive to Cyd at concentrations higher than $1 \mathrm{~mm}$. However, the Cyd toxicity can be minimized if the medium was also supplied with dThd (data not shown).

The colony-forming ability of the four clonal isolates was tested in either normal medium supplemented with FCS or medium with dialyzed FCS and one of the pyrimidine nucleosides. The results (Table II) show that all isolates (a) were auxotrophic for dThd, dUrd, or dCyd, (b) could not grow on either Cyd, Urd, dGuo, or dAdo at $10^{-5} \mathrm{M}$ but could grow in $10^{-3} \mathrm{M}$ Urd, and (c) were resistant to $10^{-7} \mathrm{M} 5$-FUrd, which kills the parental V79 cells. The results of a plating experiment (Fig. 4) not only confirm dThd auxotrophy of two isolates tested (42 and 43), but also indicate their resistance to $10^{-3} \mathrm{M}$ dThd; V79 cells do not form colonies in medium with $5 \times 10^{-4} \mathrm{M}$ dThd. Furthermore, all variants were resistant to araCyd at concentrations $\left(10^{-7}\right.$ to $5 \times 10^{-7} \mathrm{M}$ ) that kill parental cells (data not shown).

Other Biological and Biochemical Characteristics of the Variants. The 


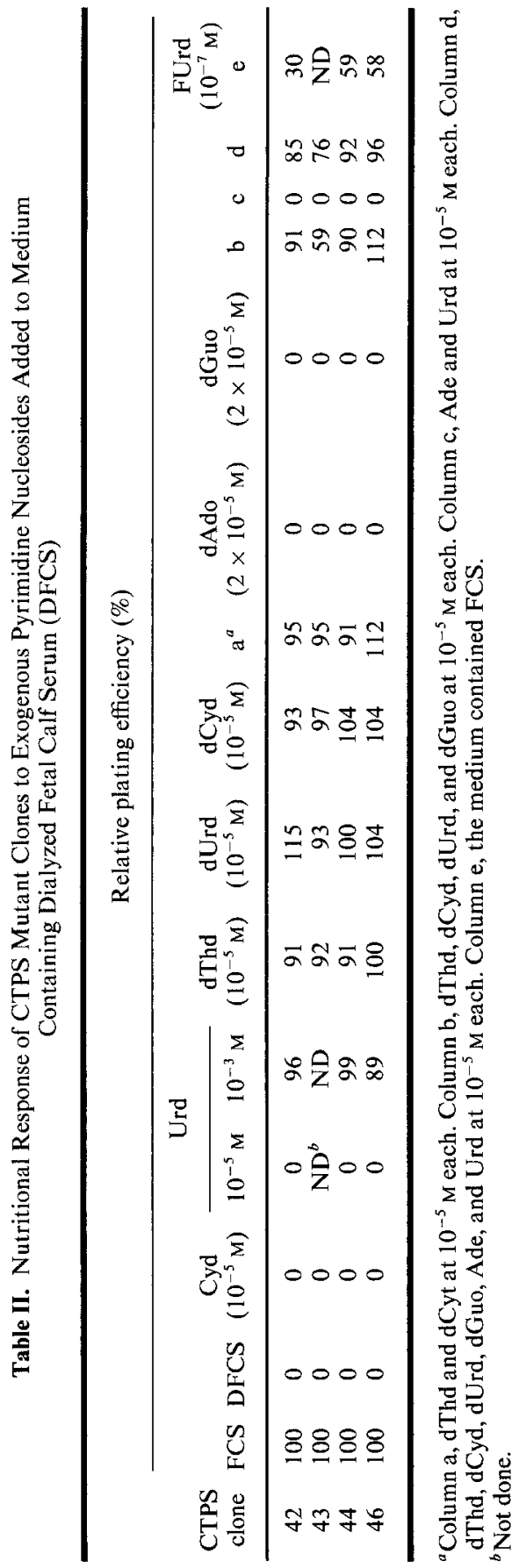




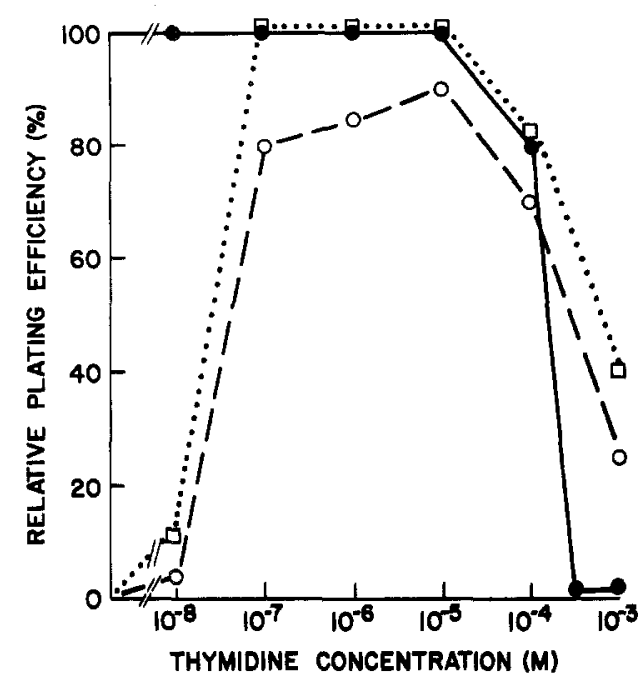

Fig. 4. Relative plating efficiency (\%) of V79 cells $(\bullet)$ and two CTP synthetase mutant derivatives [CTPS $42(0)$ and CTPS $43(\square)$ ] in graded concentrations of added thymidine in the medium.

four variants exhibited slower growth rates and plating efficiencies than the parental cells in medium supplemented with $5 \%$ FCS but no additional dThd.

CTPS is an allosteric enzyme showing positive cooperative binding of substrates (McPartland and Weinfeld, 1979). The enzymatic reaction does not exhibit Michaelis-Menten kinetics. The detailed kinetic data of the parental and variant cells are presented in the following paper.

The pleiotropic phenotypes of CTPS $42,43,44$, and 46 cells, including the joint resistance of araCyd and dThd, expanded CTP and dCTP pools (see below), and altered kinetic properties of the enzyme, were stable over several months of continuous culture of the cell lines. After fusion between CTPS 42 and $\mathrm{CHO}$ AUX Bl cells, 29 tetraploid cell hybrids were isolated in growth medium supplemented with dialyzed FCS. All 29 hybrid clones were resistant to $5 \times 10^{-7} \mathrm{M}$ araCyd and $1.5 \times 10^{-3} \mathrm{M}$ dThd, indicating that the joint resistance phenotype was a dominant trait in the hybrid. Tetraploid hybrids produced by other fusions were not resistant to these two compounds at the concentrations indicated. Reversion from dThd auxotrophy to prototrophy occurred at a frequency of approximately $10^{-5}$. The properties of CTPS in cell hybrids and revertants have not been characterized.

Intracellular Nucleotide Pools. Table III shows the results of HPLC analysis of cellular nucleoside triphosphate levels using extracts of V79 and 
Table III. Relative Cellular Nucleoside Triphosphate Levels in Extracts of Chinese Hamster V79 Cells and Four CTP Synthetase Mutant Derivatives as Measured by

High-Performance Liquid Chromatography (HPLC)

\begin{tabular}{|c|c|c|c|c|c|}
\hline & \multicolumn{5}{|c|}{ Cell extract } \\
\hline & V79 & CTPS 42 & CTPS 43 & CTPS 44 & CTPS 46 \\
\hline \multicolumn{6}{|l|}{$\begin{array}{l}\text { Percentage distribution of nucleo- } \\
\text { side triphosphates }\end{array}$} \\
\hline CTP & 4.51 & 7.03 & 22.86 & 14.64 & 21.99 \\
\hline UTP & 13.06 & 7.24 & 12.54 & 7.80 & 7.49 \\
\hline ATP & 62.95 & 67.37 & 51.11 & 56.47 & 54.00 \\
\hline GTP & 19.49 & 18.36 & 13.49 & 21.09 & 16.52 \\
\hline \multicolumn{6}{|l|}{$\begin{array}{l}\text { Ratio of nucleoside triphosphates, } \\
\text { relative to ATP }(\times 100)\end{array}$} \\
\hline CTP & 7.16 & 10.4 & 44.7 & 25.9 & 40.7 \\
\hline UTP & 20.7 & 10.7 & 24.5 & 13.8 & 13.9 \\
\hline ATP & 100.0 & 100.0 & 100.0 & 100.0 & 100.0 \\
\hline GTP & 31.0 & 27.3 & 26.4 & 37.3 & 30.6 \\
\hline Ratio, \% CTP/\% UTP & 0.345 & 0.971 & 1.82 & 1.88 & 2.94 \\
\hline $\begin{array}{l}\text { Percentage of nucleoside triphos- } \\
\text { phates as pyrimidines }\end{array}$ & 17.57 & 14.27 & 35.40 & 22.44 & 29.48 \\
\hline $\begin{array}{l}\text { Percentage of nucleoside triphos- } \\
\text { phates as purines }\end{array}$ & 82.43 & 85.73 & 64.60 & 77.56 & 70.52 \\
\hline $\begin{array}{l}\text { Ratio, percentage of pyrimi- } \\
\text { dines/percentage of purines }\end{array}$ & 0.213 & 0.166 & 0.548 & 0.289 & 0.418 \\
\hline
\end{tabular}

four variant cell lines. The information for each cell extract is presented in five ways: (a) the percentage distribution of the four nucleoside triphosphates, (b) the ratio of individual nucleoside triphosphate relative to ATP, (c) the ratio of CTP/UTP, (d) the percentage distribution of pyrimidines and purines, and (e) the ratio of percentage pyrimidines/percentage purines.

The cell extracts of all four variants had substantially higher ratios of CTP/UTP than the V79 extract. The elevation of CTP in the variants is also evident in the percentage distribution of the triphosphates, as well as the ratio of the triphosphates relative to ATP. Each of the four variants also exhibited a distinctive nucleoside triphosphate profile.

A comparison of the percentage distribution of pyrimidines and purines reveals a diversity not only between the parental and the variant cell lines but also among the variant lines. Moreover, there is no evidence for a conservation of "percentage total pyrimidines" in all the variants, i.e., the increase in CTP levels did not generate a corresponding decline in UTP levels. Consequently, all the variants have "unbalanced" pyrimidine pools.

The intracellular nucleotide pools were also measured by in vitro polynucleotide synthesis, using RNA or DNA polymerases and synthetic oligonucleotides as templates. The CTP pool was about five times higher in a 
CTPS 43 cell extract than in a V79 cell extract (data not shown). The mean dTTP pools in V79, CTPS 42, and CTPS 43 cells were, respectively, 1.68, 2.72 , and $2.5 \mathrm{pmol} / \mu \mathrm{g}$ cell DNA. The mean dCTP pools of the same cell lines were $6.08,30.81$, and $24.30 \mathrm{pmol} / \mu \mathrm{g}$ cell DNA. Thus, CTPS 42 and $43 \mathrm{had}$ 1.5 times as much dTTP and a four- to five-fold increase in dCTP, compared to V79 cells.

\section{DISCUSSION}

CTP synthetase is a rate-limiting enzyme catalyzing the irreversible conversion of UTP to CTP. The enzyme has been detected in a variety of cells and has been isolated and purified from Escherichia coli and bovine liver. The enzyme activity is specifically inhibited in vivo and in vitro by 3-deaza UTP, a major metabolite of the antitumor agent DAU (Brockman et al., 1975; McPartland and Weinfeld, 1976). The inhibition of the conversion of UTP to CTP by deaza UTP was demonstrated in a purified preparation of calf liver CTPS and in extracts of mouse leukemia L1210 cells. The enzymatic synthesis of CTP is effectively inhibited by 3-deaza UTP (McPartland et al., 1974); the average $K_{i}$ value was found to be $5.3 \times 10^{-6} \mathrm{M}$ and the inhibitor was competitive with UTP. Neither DAU nor 3-deaza UMP inhibited the enzyme activity significantly. Furthermore, inhibition of growth of L-1210 cells by 3-deaza UTP could be reversed by Cyd, dCyd, and Urd but not by dThd or dUrd.

DAU is highly toxic to V79 cells (Figs. 1 and 2). This toxicity can be reversed by Cyd and, to a lesser extent, by Urd but not by dThd or dUrd. Thus, in V79 cells the metabolites of DAU (specifically 3-deaza UTP) probably inhibit CTPS, leading to the depletion of cellular CTP and dCTP. This conclusion is reinforced by the finding that the killing of V79 cells by [5- $\left.{ }^{3} \mathrm{H}\right]$ Urd could be prevented by DAU and Cyd (Fig. 3). It has been shown that in L1210 cells in culture DAU inhibited the incorporation of $\left[5-{ }^{3} \mathrm{H}\right] \mathrm{Urd}$ into both the ribonucleotides of RNA and the dCTP of DNA (Brockman $e t$ al., 1975).

Following chemical mutagenesis and three rounds of mutant enrichment by selective killing of wild-type cells via tritium suicide, a clone (CPH 2-2) was isolated. Compared to V79 cells, this cell line exhibited an increased sensitivity to DAU and a reduced CTPS activity.

The CPH 2-2 cells were treated with EMS, followed again by selection with $\left[5-{ }^{3} \mathrm{H}\right]$ Urd, DAU, and Cyd. Among 50 surviving colonies that were isolated, none were Cyd auxotrophs with a total deficiency in CTP synthetase activity. It remains unknown whether or not a total deficiency of this enzyme is compatible with cell survival, DNA replication (Prem veer Reddy and Pardee, 1980), and cell proliferation. 
Robert de Saint Vincent et al. (1980) showed that in dCMP deaminasedeficient variants of another line of Chinese hamster lung cells (CCL 39), 5 $\mathrm{mM}$ exogenous Cyd induced a thymidineless state through the inhibition of UDP reduction. The depletion of the dTTP pools by exogenous Cyd leads to the death of the variants. However, wild-type growth, plating efficiency, and dTTP pool levels were restored in these variants if the medium was supplemented with dThd or dUrd. Chang et al. (1981) showed that V79 cells, the parental line used in the present studies, appear to be deficient in dCMP deaminase activity. Our result is consistent with this conclusion. This constitutive dCMP deaminase deficiency apparently does not affect the proliferative growth or plating efficiency of V79 cells under normal culture conditions. Since dCyd could support growth of the variant cells (Table I), Cyd deaminase (EC 3.5 4.5) may be intact in V79 cells. However, the conversion from cytidine nucleotides to thymidine nucleotide through this route is inefficient, because in the absence of exogenous dCyd our CTPS variants became dependent on dThd. V79 cells therefore have only one main pathway to synthesize dTTP, i.e., through the UDP reductase which is inhibitable by CTP (Robert de Saint Vincent et al., 1980).

The CTPS variants of V79 cells we isolated shared certain similar properties with the araCyd/excess dThd-resistant CCL 39 cells studied by Robert de Saint Vincent and co-workers (1979). These include (a) joint resistance to araCyd and excess $\mathrm{dThd}$, (b) dThd auxotrophy, (c) Cyd toxicity and its prevention by dThd, (d) expanded pools of CTP and dCTP, and (e) resistance of CTPS activity to end-product feedback inhibition. The requirements of dThd or $10^{-3} \mathrm{M}$ Urd (but not $10^{-5} \mathrm{M}$ Urd) for growth and resistance to toxic levels of FUrd of the V79 CTPS variants (Table II) can be explained by the suggestion that the permanently enlarged CTP pool in these cells inhibits UDP reduction (Robert de Saint Vincent et al., 1980). A specific increase in the CTP pool with preservation of a normal UTP pool has also been observed in rat hepatomas (Williams et al., 1978).

There are, however, notable differences between the two groups of variants, aside from the fact that they were of different cell lineage and obtained by different methods of selection. First, the CTPS variants of V79 cells we studied were resistant to araCyd/dThd and $10 \mu \mathrm{M}$ DAU. Second, our CTP variants had a much lower CTPS activity than the wild-type V79 cells and the variant enzymes were almost completely refractory to CTP inhibition (cf. the following paper). The kinetic constants for UTP and the altered nucleotide pools (Table III) of the four variants were different from the parental cells and from each other. We have interpreted this to mean that independent mutational events at the structural gene locus for CTPS in each of the four variant clones have occurred. The mutations were probably induced following treatment of cells with a known chemical mutagen. These variants are henceforth referred to as CTPS "mutants." The existence of 
markedly different nucleotide pool phenotypes in different mutants is difficult to understand. One possibility is that each mutant clone contains an additional mutation(s) affecting pyrimidine or purine metabolism.

By cell hybridization, the joint resistance phenotype appeared to be a dominant trait, in agreement with the findings of Robert de Saint Vincent and Buttin (1979). On the other hand, reversions from dThd auxotrophy to prototrophy occurred at a frequency of approximately $10^{-5}$, a feature shared by dThd auxotrophs of other Chinese hamster cell lines isolated through direct, single-step selection for resistance to either araCyd or excess dThd (Meuth et al., 1979b; Robert de Saint Vincent and Buttin, 1980). One possible explanation for the apparent difference between the two types of CTPS variants is the finding that the control exerted by CTP on this enzyme activity takes place at a site distinct from the UTP binding site (McPartland and Weinfeld, 1979). Thus, the variants studied by Robert de Saint Vincent and Buttin (1980) might have altered the regulation of CTPS by affecting only the CTP feedback inhibition while entirely preserving its catalytic activity. It is also possible that the defect occurred at a regulatory site other than the CTPS locus.

When the pools of DNA precursors become unbalanced, DNA synthesis is increasingly error prone. For instance, the fidelity of $\phi \mathrm{X} 174$ replication in vitro can be altered by varying the 2 -deoxyribonucleoside triphosphate (dNTP) levels (Weymouth and Loeb, 1978). The mutation rate is increased in thymine-starved bacteria (Bresler et al., 1973; Smith et al., 1973) and yeast (Barclay and Little, 1978; Kunz and Haynes, 1982). Similarly in mammalian cells, imbalance in intracellular DNA precursor pools as a result of either an excessive supply of exogenous nucleosides (Bradley and Sharkey, 1978; Peterson et al., 1978; Peterson and Peterson, 1979) or a genetic alteration (Meuth et al., 1979a; Weinberg et al., 1981) has led to a significant elevation of mutations. Using two independent genetic markers (resistance to 6-thioguanine or ouabain), we have compared the spontaneous mutation rates among the CTPS mutants and the parental cells. Our preliminary results (data not shown) indicate apparently higher spontaneous mutation rates at both loci in CTPS 42 and 43 than in V79 cells. By applying appropriate statistical methods for the comparison of mutation rates, we have shown that the spontaneous mutation rate from 6-thioguanine sensitivity to resistance in CTPS 46 cells was significantly higher than that of the parental cells ( $\mathrm{Li}$ et al., 1983).

\section{ACKNOWLEDGMENTS}

Dr. Pamela Moore Mattes participated in the initial phase of this study. We thank Dr. Chia-Cheng Chang for helpful discussions and Lisa Campeau for typing the manuscript. 


\section{REFERENCES}

Barclay, B. J., and Little, J. G. (1978). Genetic damage during thymidylate starvation in Saccharomyces cerevisiae. Mol. Gen. Genet. 160:33.

Bradley, M. O., and Sharkey, N. A. (1978). Mutagenicity of thymidine to cultured Chinese hamster cells. Nature 274:607.

Bresler, S. E., Mosevitsky, M. I., and Vyacheslavov, L. G. (1973). Mutations as possible replication errors in bacteria growing under conditions of thymine deficiency. Mutat. Res. 19:281.

Brockman, R. W., Shaddix, S. C., Williams, M., Nelson, J. A., Rose, L. M., and Schabel, F. M., Jr. (1975). The mechanism of action of 3-deazauridine in tumor cells sensitive and resistant to arabinosylcytosine. Ann. N.Y. Acad. Sci. USA 255:501.

Chang, C. -C., Boezi, J. A., Warren, S. T., Sabourin, C. L. K., Liu, P. K., Glatzer, L., and Trosko, J. E. (1981). Isolation and characterization of a UV-sensitive hypermutable aphidicolinresistant Chinese hamster cell line. Somat. Cell Genet. 7:235.

Cheng, Y. -C., Goz, B., and Prusoff, W. (1975). Deoxyribonucleotide metabolism in Herpes simplex virus infected HeLa cells. Biochim. Biophys. Acta 390:253.

Chu, E. H. Y., McLaren, J. D., Li, I. -C., and Lamb, B. (1982). Pleiotropic CTP synthetase mutants of Chinese hamster cells. Genetics 100:s12.

Davidson, R. L., O'Malley, K. A., and Wheeler, T. B. (1976). Polyethylene glycol-induced mammalian cell hybridization: Effect of polyethylene glycol molecular weight and concentration. Somat. Cell Genet. 2:271.

Ford, D. K., and Yerganian, G. (1958). Observations on the chromosomes of Chinese hamster cells in tissue culture. J. Nat. Cancer Inst. 21:393.

Genchev, D. D. (1973). Activity of cytidine triphosphate synthetase in normal and neoplastic tissues. Experientia 29:789.

Giles, K. W., and Myers, A. (1965). An improved diphenylamine method for the estimation of deoxyribonucleic acid. Nature 206:93.

Kunz, B. A., and Haynes, R. H. (1982). DNA repair and the genetic effects of thymidylate stress in yeast. Mutat. Res. 93:353.

Li, I. -C., Fu, J., Hung, Y. -T., and Chu, E. H. Y. (1983). Estimation of mutation rates in cultured mammalian cells. Mutat. Res. 111:253.

Lindberg, U., and Skoog, L. (1970). A method for the determination of dATP and dTTP in picomole amounts. Anal. Biochem. 34:152.

McBurney, M. W., and Whitmore, G. F. (1974). Isolation and biochemical characterization of Chinese hamster cells. Cell 2:173.

McPartland, R. P., and Weinfeld, H. (1976). Cytidine 5'-triphosphate synthetase of calf liver. J. Biol. Chem. 251:4372.

McPartland, R. P., and Weinfeld, H. (1979). Cooperative effects of CTP on calf liver CTP synthetase. J. Biol. Chem. 254:11394.

McPartland, R. P., Wang. M. C., Bloch, A., and Weinfeld, H. (1974). Cytidine 5'-triphosphate synthetase as a target for inhibition by the antitumor agent 3-deazauridine. Cancer Res. 34:3107.

Meuth, M., L'-Heureux-Huard, N., and Trudel, M. (1979a). Characterization of a mutator gene in Chinese hamster ovary cells. Proc. Natl. Acad. Sci. USA 76:6505.

Meuth, M., Trudel, M., and Siminovitch, L. (1979b). Selection of Chinese hamster cells auxotrophic for thymidine by 1- $\beta$-D-arabinofuranosyl cytosine. Somat. Cell Genet. 5:303.

Peterson, A. R., Landolph, J. R., Peterson, H., and Heidelberger, C. (1978). Mutagenesis of Chinese hamster cells is facilitated by thymidine and deoxycytidine. Nature 276:508.

Peterson, A. R., and Peterson, H. (1979). Facilitation by pyrimidine deoxyribonucleosides and hypoxanthine of mutagenic and cytotoxic effects of monofunctional alkylating agents in Chinese hamster cells. Mutat. Res. 61:319.

Pogolotti, A. L., Jr., and Santi, D. V. (1982). High-pressure liquid chromatography-ultraviolet analysis of intracellular nucleosides. Anal. Biochem. 126:335.

Prem veer Reddy, G., and Pardee, A. B. (1980). Multienzyme complex for metabolic channeling in mammalian DNA replication. Proc. Natl. Acad. Sci. USA 77:3312. 
Robert de Saint Vincent, B., and Buttin, G. (1979). Studies on 1- $\beta$-D-arabinofuranosyl cytosine-resistant mutants of Chinese hamster fibroblasts. III. Joint resistance to arabinofuranosyl cytosine and to excess thymidine-a semidominant manifestation of deoxycytidine triphosphate pool expansion. Somat. Cell Genet. 5:67.

Robert de Saint Vincent, B., and Buttin, G. (1980). Studies on 1- $\beta$-D-arabinofuranosyl cytosine-resistant mutants of Chinese hamster fibroblasts. IV. Altered regulation of CTP synthetase generates arabinosylcytosine and thymidine resistance. Biochim. Biophys. Acta 610:352.

Robert de Saint Vincent, B., Déchamps, M., and Buttin, G. (1980). The modulation of the thymidine triphosphate pool of Chinese hamster cells by dCMP deaminase and UDP reductase. J. Biol. Chem. 255:162.

Rose, L. M., and Brockman, R. W. (1977). Analysis by high-pressure liquid chromatography of 9- $\beta$-D-arabinofuranosyladenine 5 '-triphosphate levels in murine leukemia cells. J. Chromatogr. 133:335.

Skoog, L. (1970). An enzymatic method for the determination of dCTP and dGTP in picomole amounts. Eur. J. Biochem. 17:202.

Smith, M. D., Green, R. R., Ripley, L. S., and Drake, J. W. (1973). Thymineless mutagenesis in bacteriophage T4. Genetics 74:393.

Taylor, R. T., and Hanna, M. L. (1977). Folate-dependent enzymes in cultured Chinese hamster cells: Folylpolyglutamate synthetase and its absence in mutants auxotrophic for glycine + adenosine + thymidine. Arch. Biochem. Biophys. 181:331.

Urlaub, G., and Chasin, L. A. (1980). Isolation of Chinese hamster cell mutants deficient in dihydrofolate reductase activity. Proc. Natl. Acad. Sci. USA 77:4216.

Weinburg, G., Ullman, B., and Martin, D. W., Jr. (1981). Mutator phenotypes in mammalian cell mutants with distinct biochemical defects and abnormal deoxyribonucleoside triphosphate pools. Proc. Natl. Acad. Sci. USA 78:2447.

Weymouth, L. A., and Loeb, L. A. (1978). Mutagenesis during in vitro DNA synthesis. Proc. Natl. Acad. Sci. USA 75:1924.

Williams, J. C., Kizaki, H., Weber, G., and Morris, H. P. (1978). Increased CTP synthetase activity in cancer cells. Nature 271:71. 